\title{
Making Good Decisions: Media and the Physical Health of Young Children, A Parent's Tip Sheet ${ }^{1}$
}

Stephanie C. Toelle and David C. Diehl ${ }^{2}$

Many parents are concerned that the amounts of time their children watch television, play video games, or use computers may affect their children's health. Media coverage about increasing rates of childhood obesity and overweight has fueled these concerns.

It is true that there has been a dramatic increase in the number of overweight children over the past few decades, so parents are right

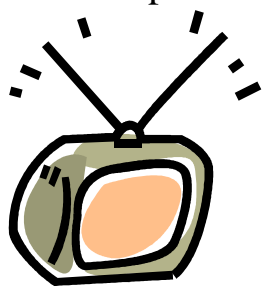

to be concerned. Serious

health risks associated with being overweight include asthma, sleep apnea, type 2 diabetes, high blood pressure, joint problems, and depression.

Parents can consider a few things to determine if their children's screen time is healthy time:

- the amount of time their children are in front of a screen

- whether screen time keeps their children from active play

- how the message on the screen affects eating habits

- how time in front of a screen affects what children eat/drink

\section{Key Findings from Research}

Research tells us a lot about the impact of television and computer use on children's health. ${ }^{\mathrm{i}}$ Time in front of a screen can be healthy, but must be carefully monitored by a parent.

- Excess screen time is related to children being overweight. Medical professionals recommend that children under the age of two years watch no television. Children under six years of age should watch no more than one to two hours of high-quality programming. However, more than onethird of preschool children watch more than two hours of television each day.

- Children need opportunities and encouragement to be active. Reducing screen time does not mean that children will play instead. Parents can help their children stay healthy by encouraging active play in a safe environment.

- Television affects the type of foods children eat. Commercials entice children to ask for high-fat, sugary snacks and parents may give in when their children nag them.

1. This publication is FCS2294, one of a series of the Department of Family, Youth and Community Sciences, Florida Cooperative Extension Service, Institute of Food and Agricultural Sciences, University of Florida. Published February 2009. Please visit the EDIS Web site at http://edis.ifas.ufl.edu

2. Stephanie C. Toelle, extension agent IV, Duval County Extension, Jacksonville, FL. David C. Diehl, Ph.D., assistant professor, Department of Family, Youth and Community Sciences, Cooperative Extension Service, Institute of Food and Agricultural Sciences, University of Florida, Gainesville, 32611. 
- Eating family meals together with the television off leads to healthier mealtimes. Families who eat together with the TV off eat more fruits and vegetables, and consume less chips, candy, and soft drinks than families who eat with the TV on.

- Children tend to eat more in front of the TV than while doing other sedentary activities. For example, they eat less while reading or doing crafts, perhaps because their hands are not free to eat.

\section{What Parents Can Do}

How can parents help maintain healthy weight in young children? Prevention is the key. Research suggests the following ways to avoid overweight in children."

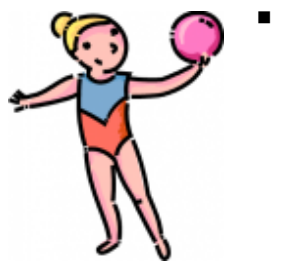

- Support or protect your community environment. Provide opportunities for children and families to enjoy activity outdoors. This may include having footpaths and trails, bicycle paths, and parks and recreation centers that are available and easy to access.

- Provide a safe environment where your children can play. Expose your children to places and activities that you feel are safe. Teach them rules to play safely. They will learn these rules as they play with friends or within your family.

- Restrict television viewing and other screen use to less than 2 hours a day (none for children under 2 years of age). Budget their TV time and choose what you let your young children watch. Be aware so that you can talk to your children about their screen usage.

- Do not allow your children to eat while watching television. Eat meals together as a family with the TV off. Children often eat more and choose less healthy foods while watching TV. Disconnecting food from TV increases awareness of what and how much you eat. It also increases family communication and decreases total TV time.

- Keep televisions and computers out of bedrooms. Children who have a TV in their room watch much more television than those who do not. Their screen time also tends to be unsupervised, which may create safety concerns as they get older.

- Avoid the influence of commercials. Mute the TV or use a DVR or $\mathrm{TiVo}^{\circledR}$ and fast-forward through commercials. Videos/DVDs are an option with no commercials! This will limit the influence of commercials featuring unhealthy foods.

- Be a role model! Eat healthfully, be active, and limit how much media you use. Your child will more likely do the same now and for the rest of his or her life.

\section{Internet Resources}

The following are reliable resources for parents interested in how they can take control of the issue of media and its impact on young children's health.

\section{American Academy of Pediatrics Media Matters}

(www.aap.org/advocacy/mediamatters.htm): Provides an overview of AAP's campaign about media and its effects on children. Site includes advocacy and policy statements, public education brochures, and downloadable presentations on media issues.

\section{American Academy of Pediatrics Overweight and Obesity}

(www.aap.org/obesity): AAP's overweight and obesity site for recommended books and brochures for parents on growing up healthy.

Centers for Disease Control and Prevention (www.cdc.gov/nccdphp/dnpa/obesity/childhoo $\mathrm{d} /$ index.htm): The CDC offers facts and tips for parents and professionals on childhood overweight and obesity concerns. 


\section{Center on Media and Child Health}

(www.cmch.tv): Created by Children's

Hospital Boston, Harvard Medical School and

Harvard School of Public Health, provides

fact sheets for parents, teachers, and

researchers.

\section{Center for Screen-Time Awareness}

(www.screentime.org): Sponsors campaigns, such as the TV Turnoff Week, to bring awareness to families regarding their media use.

\section{Children Now}

(www.childrennow.org/issues/media): A national organization that evaluates and advocates for public policy concerning children's issues, including the impact of media on children's health.

\section{CommonSense Media}

(www.commonsensemedia.org): Provides resources and reviews of movies, TV shows, games, music, books, and Web sites (includes ages 2-4 and 5-7, as well as older).

\section{Healthy Habits for Healthy Kids}

(www.wellpoint.com/healthy_parenting/index. html): A nutrition and activity guide for parents.

\section{National Institute on Media and the Family} (www.mediafamily.org/facts/facts_tvandobchi ld.shtml): NIMF sponsors the MediaWise movement. This site provides fact sheets and tips, video game report cards, Internet safety, and activities and quizzes related to media.

\section{Nutrition Explorations}

(www.nutritionexplorations.org): Information for parents and educators, plus fun online nutrition games for kids.

\section{The Center for Weight and Health}

(www.cnr.berkeley.edu/cwh/index.html): Offers programs, projects, and materials focused on childhood overweight.

We Can! (www.nhlbi.nih.gov/health/public/heart/ obesity/wecan): This federally sponsored program has three main objectives: improve food choices, increase physical activity, and reduce screen time. Although it targets families with children ages 813 , it's never too early to start adapting some of the healthy behaviors promoted through this program.

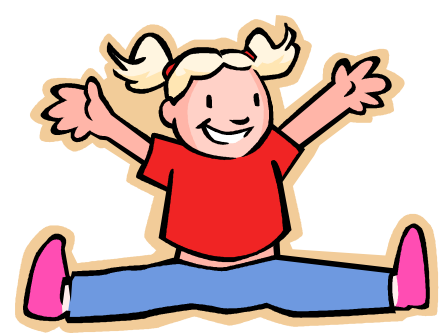

\footnotetext{
${ }^{\mathrm{i}}$ For a more detailed overview of the research, please see EDIS publication FCS2293/FY1076 Making Good Decisions: Media and the Physical Health of Young Children at http://edis.ifas.ufl.edu/FY1076.

ii

These recommendations have been adapted from the following sources: (1) Dehghan, M., Akhtar-Danesh, N., \& Merchant, A. (2005). Childhood obesity, prevalence and prevention. Nutrition Journal 4(1), 24. (2) Center on Media and Child Health Tips for Media Use. Available at: www.cmch.tv/mentors_parents/overweight_suggestions.asp; (3) Jordan, A., Robinson, T.N. (2008). Children, television viewing, and weight status: Summary and recommendations from an expert panel meeting. The ANNALS of American Academy of Political and Social Science, 615, 119-13.; and American Academy of Political and Social Science, 615, 119-13.; and, (4) U.S. Department of Health and Human Services, Office of the Surgeon General
(2007). The Surgeon General's call to action to prevent and decrease overweight and obesity: Overweight in children and adolescents. Available at: www.surgeongeneral.gov/topics/underagedrinking/call toaction.pdf.
} 